\title{
Economic Security Threat Modelling of a Commercial Bank in a Globalized Economy
}

\author{
Olena $V$. Dymchenko ${ }^{i}$ Olha O. Rudachenko ${ }^{i i}$, Patrizia Gazzola ${ }^{i i i}$
}

\begin{abstract}
In the paper, one develops a set of models for diagnosing threats to the economic security of a commercial bank, which allows improving the quality of decisions forming and making on managing the safe functioning and development of the bank. The bank's economic security research system has been developed, it includes 3 main blocks: research information space creation; assessment and analysis of the security of a commercial bank; generalization, and formation of decisions on the economic security of a commercial bank.

The research made it possible to draw an inference of a theoretical, methodological, and applied nature that reflects the solution of the tasks set following the purpose of the study. A set of models has been built with modern tools of economic and mathematical modelling to improve the quality of decisions made to manage the bank's security and reduce the risks of threats. A model for calculating the bank's economic security indicator has been developed, which includes the following main stages: the construction of a structural scheme taking into account the rules of the theory of banking functioning security, then the terms and their membership functions are set for each input and output variable of the fuzzy inference system under consideration. Results of the response surface for the model are shown in the figure on the graphs of the dependence of the bank's economic security indicator on various input components. The paper requires that it is convenient to diagnose the state of economic security of a bank using fuzzy logic, this allows getting a clear quantitative representation of economic security state of the bank, as the indicators used for diagnostics may be indistinct and approximate and this a priori cannot give an adequate result when accurately calculated.
\end{abstract}

Key words: commercial bank, threats, economic security, modelling, neural networks, management solutions.

Introduction. In the context of the globalized world economy, ensuring the economic security of a commercial bank is becoming an increasingly vital issue as economic security is an integral component of the national security system, its foundation. The emergence of this category stems from the market transformation of the economy and the Ukraine desire to integrate into the system of foreign economic relations, as the development of the Ukrainian economy directly depends on the state of the banking system.

${ }^{i}$ Olena V. Dymchenko, Dr. (Economics), Professor of the Department of Entrepreneurship and Business Administration of the O. M. Beketov Kharkiv National University of Urban Economy;

${ }^{i i}$ Olha O. Rudachenko, Ph.D. in Economics, Assistant Professor of the Department of Entrepreneurship and Business Administration of the O. M. Beketov Kharkiv National University of Urban Economy;

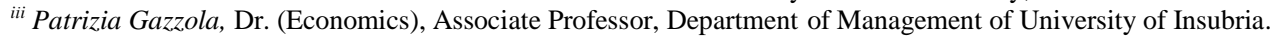

(C) O. V. Dymchenko, O. O. Rudachenko, P. Gazzola, 2020.

https://doi.org/10.21272/mer.2020.89.11 
Olena V. Dymchenko, Olha O. Rudachenko, Patrizia Gazzola

Economic Security Threat Modelling of a Commercial Bank in a Globalized Economy

Economic security issues arise for every commercial bank both in the conditions of stable development and in times of crisis, a necessary prerequisite for the bank`s economic security is to ensure the stable position of the credit institution itself and its main components. Therefore, banking institutions began to pay more and more attention to the issue of diagnostics and analysis of the economic security of the bank as a whole. Most often, the bank's survival in our difficult economic conditions depends on its ability to identify and cope with various banking risks in time, which are a very complex, unstable, high-tech environment. So by developing diagnostics methods of bank economic security one determines the security state of the bank, establishes the influence of some factors of structure and environment on the other, identifies possible problems in the functioning structure, weaknesses («bottlenecks»), their causes and identify ways of elimination of the violations and deviations with the purpose of bringing this to normal functioning.

Thus, the most important issue for any bank is the state of economic security, as one of the main directions of effective management of the bank's activities, and the main goal is to ensure maximum protection of the economic components of banking activities.

Analysis of recent research and publications. The banking system security has been studied in the papers of both foreign and domestic scientists, such as: O. F. Balatsky, O. I. Baranovsky, I. O. Blank, M. Z. Bora, S. Bukin, J. K. Van Horn, O. D. Vasylyk, V. V. Vitlinsky, V. M. Heyets, K. S. Horyacheva, R. Hrytsenko, L. S. Guryanova, V. H. Zahorodnii, O. D. Zaruba, T. S. Klebanova, R. J. Campbell, L. A. Kluska, I. P. Kozachenko, V. H. Kryzhanivska, I. M. Krupka, L. O. Lihonenko, I. O. Lutii, T. V. Momot, A. M. Moroz, V. P. Moskalenko, V. I. Muntiyan, O. O. Oleynikov, E. S. Osadchy, B. A. Reisberg, M. I. Savluk, J. F. Sinki, T. S. Smovzhenko, V. I. Sribniy, O. O. Tereshchenko, R. I. Schiller etc. However, some issues related to threats to the economic security of commercial banks modelling remain insufficiently studied and require detailed research.

The purpose of the article - is to develop a set of models for diagnosing threats to the economic security of a commercial bank, which will improve the quality of forming and making decisions on managing the safe functioning and development of the bank.

Research result. Modern tendencies of banking system development in Ukraine confirm that most national banks have moved from a state of solving the issues solely associated with survival to the ones of business development, the need of capitalization, expansion, preservation of assets, creation of new innovative banking products, finally, building a system of corporate governance that is conformed with modern realities. It is the problems of complex diagnostics of economic security, determining the current state of the bank's security, identifying the impact of various factors, estimating possible problems and shortcomings in the structure of functioning, the causes of their occurrence and identify ways to eliminate the detected violations and deviations in order to bring it to normal functioning, that is of particular importance and relevance in modern Ukrainian banking management.

The system of economic security of a commercial bank (ESCB) can be represented as a set of three closely interrelated subsystems [1, 2]: credit and financial security, information security, a subsystem for monitoring and evaluating the result.

All subsystems are interconnected and interact closely with each other within the framework of the economic security system. A negative change in any, even one, component can cause significant harm to the normal functioning of any of the subsystems, as well as lead to negative consequences for the entire system of economic security of a commercial bank. 
If one considers the system of economic security in details, clearly understands what to do and how to do it, at each stage, for the safe and cost-effective functioning of such a scheme will not be enough, because it only gives an idea of the relationship of the components of the system and does not reflect clear methods for diagnosing economic security. Therefore, the authors developed a system for investigating the bank's economic security, which includes 3 main blocks:

1. Block for forming the research information space.

2. Assessment and analysis of commercial bank security.

3. Decisions generalization and formation concerning on the economic security of commercial bank.

The first step of the investigation - block for forming the research information space - one identified the main indicators characterizing the efficiency and the state of economic security of the bank and in accordance with the regulations, determined their threshold values, this gives a clear understanding the state of economic security of the bank. As a result of the analysis of scientific approaches to the assessment of economic security [3-5], one identified the prominent indicators that most clearly characterize the effectiveness of work and the state of economic security. It is most appropriate to include such economically justified indicators: K1 (profitability ratio of the assets), H2 (regulatory capital adequacy), H3 (ratio of regulatory capital to the total assets), H4 (bank performance), H5 (current liquidity), H6 (capital adequacy), K3 (credit risk ratio), K4 (maximum credit risk per counterparty), K5 (performance at interest rates), E (security status).

The normative values of indicators that characterize the level of economic security of a commercial bank are presented in table $1[1,6]$.

Table 1

Normative values of indicators

\begin{tabular}{|l|l|}
\hline \multicolumn{1}{|c|}{ Indicator } & \multicolumn{1}{|c|}{ Normative value } \\
\hline profitability ratio of the assets (K1) & no less than $1,5 \%$ \\
\hline regulatory capital adequacy (H2) & no less than $10 \%$ \\
\hline ratio of regulatory capital to the total assets (H3) & no less than $9 \%$ \\
\hline bank performance (H4) & no less than $10 \%$ \\
\hline current liquidity (H5) & no less than $40 \%$ \\
\hline capital adequacy (H6) & no less than $4 \%$ \\
\hline credit risk ratio (K3) & no more than 1 \\
\hline maximum credit risk per counterparty (K4) & no more than $25 \%$ \\
\hline performance at interest rates (K5) & more than 1 \\
\hline
\end{tabular}

This set of indicators was used to diagnose and forecast the bank's economic security.

The second step of the investigation - is the block of assessment and analysis of economic security of a commercial bank - the main models of assessment and diagnostics of economic security of a bank are defined, as well as their construction and conclusions about the current state of the bank and its possible improvement steps are made.

The third stage of the investigation - the block of generalization and formation of decisions on the management of economic security of a commercial bank. 
Olena V. Dymchenko, Olha O. Rudachenko, Patrizia Gazzola Economic Security Threat Modelling of a Commercial Bank in a Globalized Economy

The information basis for calculations are the economic indicators of the bank's functioning in quarterly terms. Alfa-Bank is an example of such a bank [6-7].

Firstly, the input data was standardized in quarterly terms. Using standardization of the input data one calculated integrated evaluation of economic safety, an integrated assessment of the upper pole, and quarterly indexes of economic security on the basis of integral assessments. Summarized calculations are shown in table 2.

Table 2

Standardized quarterly safety factors

\begin{tabular}{|c|c|c|c|c|c|c|c|c|c|}
\hline K1 & H2 & H3 & H4 & H5 & H6 & K3 & K4 & K5 & Ave. \\
\hline 0,869 & 0,814 & 0,902 & 0,998 & 0,971 & 0,67 & 1,395 & 1,214 & 0,896 & 0,97 \\
\hline 1,039 & 0,866 & 0,939 & 0,897 & 0,985 & 0,714 & 1,348 & 1,188 & 0,913 & 0,988 \\
\hline 0,99 & 0,827 & 0,926 & 1,006 & 0,858 & 0,679 & 1,283 & 1,085 & 0,976 & 0,959 \\
\hline 1,032 & 0,766 & 0,846 & 1,201 & 1,065 & 0,78 & 1,304 & 1,156 & 0,996 & 1,016 \\
\hline 1,094 & 0,737 & 0,854 & 0,967 & 1,095 & 0,676 & 1,033 & 1,16 & 0,902 & 0,946 \\
\hline 1,054 & 0,949 & 0,967 & 1,24 & 0,991 & 0,76 & 1,262 & 1,122 & 0,936 & 1,031 \\
\hline 1,061 & 0,968 & 1,039 & 1,302 & 1,058 & 1,087 & 1,395 & 1,22 & 0,981 & 1,124 \\
\hline 1,099 & 0,86 & 0,923 & 1,208 & 0,851 & 1,028 & 1,075 & 1,236 & 1,016 & 1,033 \\
\hline 1,102 & 0,871 & 0,877 & 1,279 & 0,872 & 1,164 & 1,153 & 0,99 & 1,103 & 1,046 \\
\hline 0,961 & 0,802 & 0,869 & 1,154 & 0,868 & 1,017 & 1,559 & 1,016 & 1,016 & 1,029 \\
\hline 1,004 & 0,838 & 0,853 & 1,13 & 0,741 & 1,059 & 1,02 & 1,06 & 0,993 & 0,966 \\
\hline 1,104 & 0,949 & 0,87 & 1,084 & 0,709 & 1,018 & 0,958 & 1,027 & 0,976 & 0,966 \\
\hline 1,075 & 1,023 & 1,011 & 0,675 & 0,741 & 0,7 & 0,75 & 1,123 & 0,823 & 0,88 \\
\hline 0,854 & 1,001 & 0,878 & 0,623 & 0,731 & 0,766 & 0,812 & 0,975 & 0,89 & 0,837 \\
\hline 0,99 & 0,957 & 0,921 & 0,669 & 0,713 & 0,778 & 0,652 & 0,895 & 0,999 & 0,841 \\
\hline 0,954 & 1,029 & 1,031 & 0,65 & 0,715 & 0,695 & 0,686 & 0,688 & 1,016 & 0,829 \\
\hline 0,819 & 1,072 & 1,015 & 0,756 & 0,864 & 1,078 & 0,772 & 1,027 & 1,014 & 0,935 \\
\hline 0,854 & 1,087 & 1,012 & 0,787 & 1,031 & 1,145 & 0,803 & 0,843 & 1,023 & 0,954 \\
\hline 0,712 & 1,029 & 0,986 & 0,873 & 1,047 & 1,072 & 0,743 & 0,837 & 1,019 & 0,924 \\
\hline 0,783 & 1,095 & 1,083 & 0,967 & 1,136 & 1,136 & 0,73 & 0,924 & 1,013 & 0,985 \\
\hline 0,783 & 1,103 & 1,018 & 0,912 & 1,153 & 1,094 & 0,803 & 0,902 & 0,987 & 0,973 \\
\hline 1,068 & 1,131 & 1,051 & 1,084 & 1,252 & 1,095 & 0,828 & 0,911 & 1,028 & 1,05 \\
\hline 1,054 & 1,206 & 1,088 & 1,029 & 1,02 & 1,2 & 0,846 & 0,971 & 1,065 & 1,053 \\
\hline 1,139 & 1,177 & 1,136 & 1,06 & 1,357 & 1,2 & 0,874 & 0,931 & 1,047 & 1,102 \\
\hline 1,154 & 1,201 & 1,179 & 1,13 & 1,254 & 1,3 & 0,958 & 0,893 & 1,056 & 1,125 \\
\hline 1,196 & 1,159 & 1,162 & 1,115 & 1,242 & 1,376 & 0,914 & 0,841 & 1,153 & 1,129 \\
\hline 1,068 & 1,221 & 1,246 & 1,099 & 1,361 & 1,359 & 1,06 & 0,862 & 1,136 & 1,157 \\
\hline 1,089 & 1,264 & 1,318 & 1,107 & 1,32 & 1,354 & 0,982 & 0,903 & 1,033 & 1,152 \\
\hline
\end{tabular}

After such calculations, we get integral estimates of economic security, which are shown in the form of a histogram in fig. 1, which can already be used to draw certain conclusions and develop a strategy for safe management. 


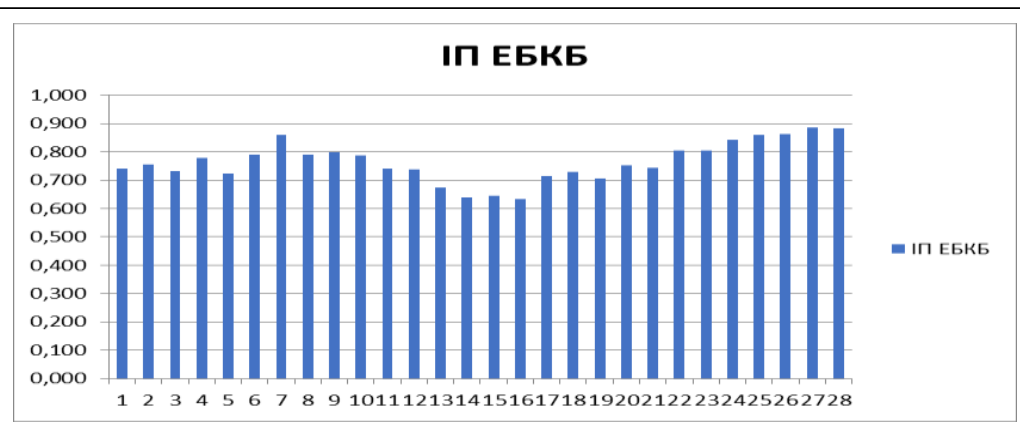

Figure 1. Integrated assessments of economic security

Having analyzed the obtained data, one concludes that the level of economic security of Alfa-Bank is quite high, it is within 1.

Thus, the construction of a model of credit and financial economic security using the method of standardization of input variables, which makes the input economic indicators comparable, allows to obtain a clear and pretty adequate assessment of the bank's economic security.

Having determined the state of bank economic security, we have conducted the diagnostics of threats to economic security. The construction of the commercial bank`s economic security diagnostic model was performed using fuzzy logic in the application package MATLAB [8]. The mathematical theory of fuzzy logic is a generalization of classical set theory and classical formal logic. This concept was first proposed by the American scientist L. Zadeh in 1965. The main reason for this theory to appear was the availability of odd and approximate reasoning when describing human processes, systems, and objects [9]. Therefore, fuzzy logic was used to build a model for diagnosing the state of economic security of the bank.

The algorithm of the bank's economic security diagnostics model is based on statistical information about the workflow parameters that determine its normal functioning and level of security. The result of calculations using this method is a clear quantitative representation of the bank economic security state for each of the indicators that characterize the level of bank security.

We create a model for calculating the bank's economic security indicator, which includes the following main stages: first of all, it is the construction of a structural scheme taking into account the rules of the theory of banking functioning security, this structure was later used to create the calculation model, then the terms and their membership functions are set for each input and output variable of the fuzzy inference system under consideration. The functional block diagram for diagnostics is showed in fig. 2 and includes such components as: $\mathrm{K} 1$ (profitability ratio of the assets), $\mathrm{H} 2$ (regulatory capital adequacy), $\mathrm{H} 3$ (ratio of regulatory capital to the total assets), H4 (bank performance), H5 (current liquidity), H6 (capital adequacy), K3 (credit risk ratio), K4 (maximum credit risk per counterparty), K5 (performance at interest rates), E (security status). 
Olena V. Dymchenko, Olha O. Rudachenko, Patrizia Gazzola Economic Security Threat Modelling of a Commercial Bank in a Globalized Economy

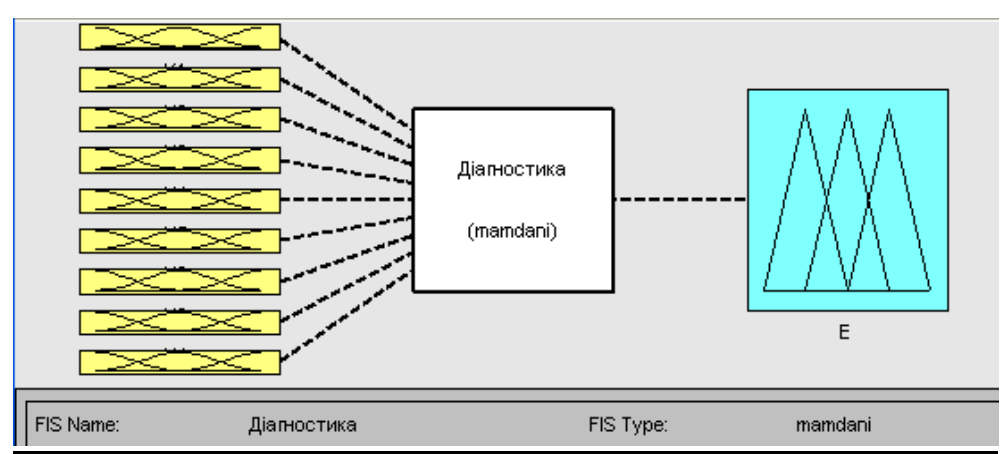

Figure 2. Block diagram for diagnostics of economic security of a commercial bank

Output parameter - E. Input - K1, H2, H3, H4, H5, H6, K3, K4, K5.

For each indicator one present such terms as: low, average and high value of the indicator of economic security of a commercial bank.

Figure 3 shows the «assets profitability» input signal. The profitability indicator should be no lower than $1,5 \%$, that is, everything below $1,5 \%$ was characterized as a low indicator of profitability of the bank, and everything above - taken as high profitability.

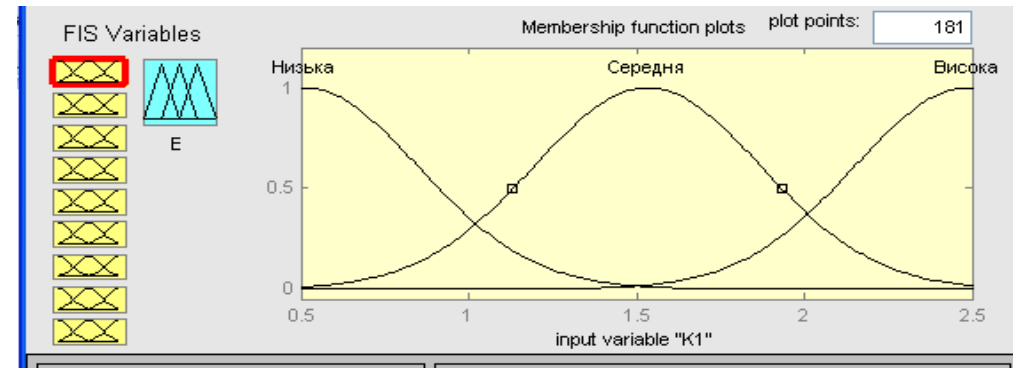

Figure 3. Submission of terms for profitability ratio of the assets

Similar work on submitting terms was also done for other bank indicators.

Further, the rules of safe and unsafe bank operation modes were created for various situations that may occur at any time. The results of building the rules showed that the change in each of the proposed indicators significantly, to a greater extent, affects the level of economic security of the bank.

Thus, let us analyze the model obtained. Graphs of the dependence of the bank's economic security indicator on various input components are shown in figure 4. 

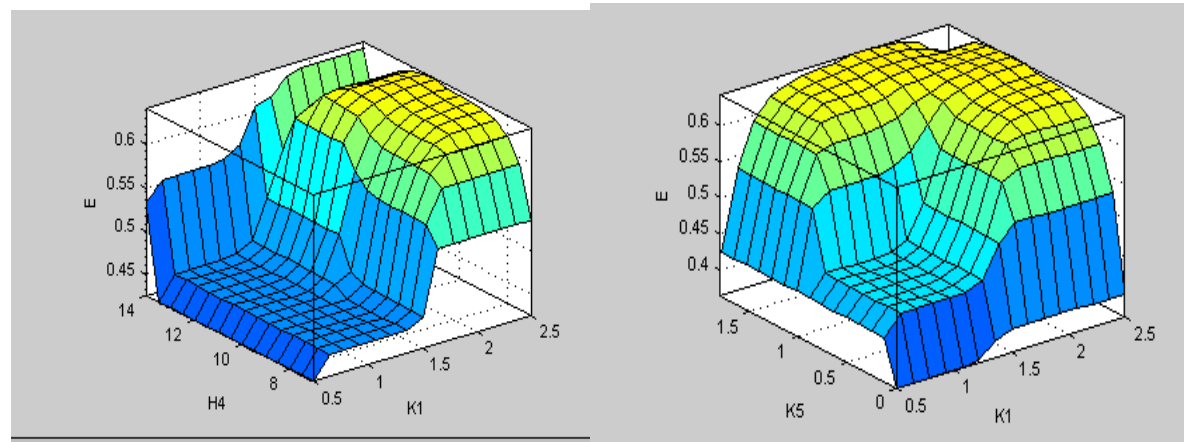

Figure 4. Results of the response surface for the model

The response surfaces are of the monotonous increase form, i. e. there are no abrupt jumps in changes of the generalizing level of economic security states.

That is, it is convenient to diagnose the state of economic security of a bank using fuzzy logic, this allows getting a clear quantitative representation of economic security state of the bank, as the indicators used for diagnostics may be indistinct and approximate, this a priori cannot give an adequate result when accurately calculated.

The models that diagnose the commercial bank`s economic security, that are considered in the paper, allow increasing the effectiveness of decisions on bank security management, due to the fact that a low level of economic security of the banking sector means the loss of stability in functioning and development of the Ukrainian economy as a whole and the loss of its ability to self-development and progress.

Conclusions and prospects for further research. The research made it possible to draw an inference of a theoretical, methodological, and applied nature that reflects the solution of the tasks set per the purpose of the study. A set of models has been built with modern tools of economic and mathematical modelling to improve the quality of decisions made to manage the bank's security and reduce the risks of threats.

The diagnostic models proposed in the paper can be successfully implemented to form management decisions and strategic directions for the economically safe operation and development of a commercial bank.

\section{References}

1. Baranovsky, O. I. (2006). Bankivska bezpeka: problema vymiru [Banking security: the measurement problem]. Ekonomichne prohnozuvannia - Economic forecasting, 1, 7-32 [in Ukrainian].

2. Klebanova, T. S., Guryanova, L. S., Bogonikolos N., Kononov O. Yu., Bersutsky Ya. H. (2006). Modelyrovanye fynansovykh potokov v uslovyiakh neopredelennosty [Financial flows modelling under uncertainty] : monograph. Kharkiv : PH "INZHEK" [in Ukrainian].

3. Epifanov, A. O., Plastun, O. L., Dombrovsky, V. S. (2010). Finansova bezpeka pidpryiemstv $i$ bankivskykh ustanov [Financial security of enterprises and banking institutions] : monograph. Sumy : DVNZ "UABS NBU" [in Ukrainian].

4. Haidyk, V. I., Vorokov, A. L., Haidyk, N. V. (2015). Finansovaya bezopasnost` kommercheskikh bankov: kriterii i indicatory [Financial security of commercial banks: criteria and indicators]. Nauchnyj zhurnal KubGAU - Scientific journal Kuban State Agrarian University, 114 (10), 1-22. Retrieved from http://ej.kubagro.ru/2015/10/pdf/06.pdf [in Russian]. 
Olena V. Dymchenko, Olha O. Rudachenko, Patrizia Gazzola

Economic Security Threat Modelling of a Commercial Bank in a Globalized Economy

5. Lisnyak, A. Ye. (2017). Chynnyky finansovoi bezpeky bankiv [Factors of financial security of banks]. Visnyk universytetu bankivskoi spravy - Bulletin of the University of Banking, 3(30), 77-82 [in Ukrainian].

6. Osnovni pokaznyky diialnosti bankiv Ukrainy [Key performance indicators of Ukrainian banks]. National Bank of Ukraine. Retrieved from http://bank.gov.ua [in Ukrainian].

7. Ofitsiinyi sait Alfa-banku Ukrainy [Official website of Alfa-Bank]. Retrieved from https://alfabank.ua [in Ukrainian].

8. Guryanova, L. S., Gvozdytskyi, V. S., Dymchenko, O. V., Rudachenko, O. A. (2018). Models of forecasting in the mechanism of early informing and prevention of financial crises in corporate systems. Financial and credit activity: problems of theory and practice, 3(26), 303-312.

9. Zadeh, L. A. (1994). Fuzzy Logic, Neural Networks, and Soft Computing. Communications of the ACM, 37(3), 77-84.

Manuscript received 07 August 2020

\title{
Моделирование угроз экономической безопасности коммерческого банка в условиях глобализации экономики
}

\section{ЕЛЕНА ВЛАДИМИРОВНА ДЫМЧЕНКО*, ОЛЬГА АЛЕКСАНДРОВНА РУДАЧЕНКО ${ }^{* *}$ ПАТРИЗИЯ ГАЗЗОЛА}

\author{
* доктор экономических наук, профессор кафедры предпринимательства и бизнес- \\ администрирования Харьковского начионального университета городского хозяйства \\ имени А.Н. Бекетова \\ ул. М. Бажанова, 17, г. Харьков, 61001, Украина, \\ тел.: +380-509-776060, e-mail: dymchenkoov@gmail.com \\ *** кандидат экономических наук, старший преподаватель кафедры предпринимательства и \\ бизнес-администрирования Харьковского национального университета городского хозяйства \\ имени А.Н. Бекетова \\ ул. М. Бажанова, 17, г. Харьков, 61001, Украина, \\ тел.: +380-935-048815, e-mail: polkin87@ukr.net \\ *** доктор экономических наук, доцент, профессор кафедры Менеджмента \\ Университета Инсубирии \\ ул. Монте Дженероссо, 71, г. Варезе, 21100, Италия, \\ тел.: +39 0332/395529, e-mail: patrizia.gazzola@ uninsubria.it
}

В статье разработан комплекс моделей диагностики угроз экономической безопасности коммерческого банка, который позволяет повысить качество формирования и принятия решений по управлению безопасным функционированием и развитием банка. Разработанная система исследования экономической безопасности банка, которая включает в себя 3 основных блока: блок формирования информационного пространства исследования; оценка и анализ безопасности коммерческого банка; обобщения и формирования решений относительно экономической безопасности коммерческого банка.

Проведенное исследование позволило сформулировать выводы теоретического, методологического и прикладного характера, отражающие решения поставленных в соответствии с целью данного исследования задач. Построен комплекс моделей, с помощью современных 
О. В. Димченко, О. О. Рудаченко, П. Газзола

Моделювання загроз економічної безпеки комерційного банку в умовах глобалізації економіки

инструментальных средств экономико-математического моделирования, позволяет повысить качество принимаемых решений по управлению безопасностью банка и снизить риски возникновения угроз.

Ключевые слова: коммерческий банк, угрозы, экономическая безопасность, моделирование, нейронные сети, управленческие решения.

\author{
Mechanism of Economic Regulation, 2020, No 3, 142-151
}

ISSN 1726-8699 (print)

\title{
Моделювання загроз економічної безпеки комерційного банку в умовах глобалізації економіки
}

\section{ОЛЕНА ВОЛОДИМИРІВНА ДИМЧЕНКО*, ОЛЬГА ОЛЕКСАНДРІВНА РУДАЧЕНКО**, ПАТРИЗІЯ ГАЗЗОЛА ${ }^{* * *}$}

* доктор економічних наук, професор кафедри підприємництва та бізнес-адміністрування Харківського начіонального університету міського господарства імені О.М. Бекетова вул. М. Бажанова, 17, м. Харків, 61001, Украӥна, тел.: +380-509-776060, e-mail:dymchenkoov@gmail.com

** кандидат економічних наук, старший викладач кафедри підприємництва та бізнесадміністрування Харківського національного університету міського господарства імені О.М. Бекетова

вул. М. Бажанова, 17, м. Харків, 61001, Украӥна, тел.:+380-935-048815, e-mail:polkin87@ukr.net

*** доктор економічних наук, доцент, професор кафедри Менеджменту Університету Інсубіріі вул. Монте Дженероссо, 71, м. Варезе, 21100, Італія,

тел.: +39 0332/395529, e-mail: patrizia.gazzola@uninsubria.it

У статті розроблено комплекс моделей діагностики загроз економічної безпеки комерційного банку, який дозволяє підвищити якість формування та ухвалення рішень з управління безпечним функціонуванням та розвитком банку. Розроблена система дослідження економічної безпеки банку, яка включає в себе 3 основні блоки: блок формування інформаційного простору дослідження; оцінка й аналіз безпеки комерційного банку; узагальнення та формування рішень, щодо економічної безпеки комерційного банку.

Проведене дослідження дало можливість сформулювати висновки теоретичного, методологічного та прикладного характеру, які відображають вирішення поставлених у відповідності 3 метою даного дослідження завдань. Побудований комплекс моделей, за допомогою сучасних інструментальних засобів економіко-математичного моделювання, дозволяє підвищити якість прийнятих рішень 3 управління безпекою банку та знизити ризики виникнення загроз.

Ключові слова: комерційний банк, загрози, економічна безпека, моделювання, нейронні мережі, управлінські рішення.

JEL Codes: G21

Tables: 2; Figures: 4; References: 9

Language of the article: English 
Olena V. Dymchenko, Olha O. Rudachenko, Patrizia Gazzola Economic Security Threat Modelling of a Commercial Bank in a Globalized Economy

Лimepamypa

1. Барановський, O. I. Банківська безпека: проблема виміру / О. І. Барановський // Економічне прогнозування. 2006. - № 1. - С. 7-32.

2. Клебанова, T. С. Моделирование финансовых потоков в условиях неопределенности : монография / Т. С. Клебанова, Л. С. Гурьянова, Н. Богониколос, О. Ю. Кононов, Я. Г. Берсуцкий. - Харьков : ИД «ИНЖЭК», 2006. - 312 с.

3. Фінансова безпека підприємств і банківських установ : монографія / за заг. ред. д-ра екон. наук, проф. А. О. Єпіфанова // А. О. Спіфанов, О. Л. Пластун, В. С. Домбровський та ін. Суми : ДВНЗ «УАБС НБУ», 2009. - 295 с.

4. Гайдук, B. I. Финансовая безопасность коммерческих банков: критерии и индикаторы [Електронний ресурс] / В. І. Гайдук, А. Л. Вороков, Н. В. Гайдук // Научный журнал КубГАУ. 2015. - № 114 (10). - С. 1-22. - Режим доступу : http://ej.kubagro.ru/2015/10/pdf/06.pdf.

5. Лісняк, А. С. Чинники фінансової безпеки банків / А. Є. Лісняк // Вісник університету банківської справи. 2017. - № 3 (30). - С. 77-82.

6. Основні показники діяльності банків України [Електронний ресурс] / Національний Банк України. - Режим доступу : http://bank.gov.ua.

7. Офіційний сайт Альфа-банку України [Електронний ресурс]. - Режим доступу : https://alfabank.ua.

8. Guryanova, L.S., Models of forecasting in the mechanism of early informing and prevention of financial crises in corporate systems / L. S. Guryanova, V. S. Gvozdytskyi, O. V. Dymchenko, O. A. Rudachenko // Financial and credit activity: problems of theory and practice. 2018. - № 3 (26). - C. 303-312.

9. Zadeh, L. A. Fuzzy Logic, Neural Networks, and Soft Computing / L. A. Zadeh // Communications of the ACM. 1994. - № 37 (3). - C. 77-84. 